\title{
Endothelin-2 synthesis is stimulated by the type-1 tumour necrosis factor receptor and cAMP: comparison with endothelin-converting enzyme-1 expression
}

\section{G L Lambert, S Barker, D M Lees and R Corder}

The William Harvey Research Institute, St Bartholomew's and the Royal London School of

Medicine and Dentistry, Queen Mary and Westfield College, Charterhouse Square Campus, London EC1M 6BQ, UK

(Requests for offprints should be addressed to R Corder; Email: R.Corder@mds.qmw.ac.uk)

\begin{abstract}
The synthesis of the vasoconstrictor peptide endothelin-2 (ET-2) is dependent on hydrolysis of the biologically inactive intermediate big ET-2 by an endothelin-converting enzyme (ECE). Here, mechanisms inducing ET-2 synthesis have been investigated using the human renal adenocarcinoma cell line (ACHN). Synthesis of ET-2 by ACHN cells was inhibited by phosphoramidon $\left(\mathrm{IC}_{50} \cong 11 \mu \mathrm{M}\right)$. To determine whether ET-2 synthesis occurs in parallel with the metallopeptidase ECE-1, a putative processing peptidase for big ET-2, changes in the levels of their mRNAs were compared by semi-quantitative RT-PCR under conditions causing the upregulation of ET-2 synthesis. Tumour necrosis factor- $\alpha$ (TNF $\alpha$ ), forskolin and a cell-permeable cAMP analogue (dibutyryl cAMP) caused concentration-dependent increases in ET-2 synthesis. Combination of forskolin or dibutyryl cAMP with TNF $\alpha$ produced a significantly greater increase in ET-2 production
\end{abstract}

than these agents alone, indicating that adenylate cyclase and TNF $\alpha$ induce ET-2 synthesis by separate signalling pathways. Studies using receptor selective TNF $\alpha$ mutants, ${ }^{125} \mathrm{I}-\mathrm{TNF} \alpha$ binding and TNF receptor mRNA showed that type-1 TNF receptors mediate the ET-2 response to TNFa. PreproET-2 mRNA levels were increased by TNF $\alpha$ at $1 \mathrm{~h}$ and $2 \mathrm{~h}$, but returned to control levels at $4 \mathrm{~h}$. Treatment with forskolin significantly increased preproET-2 mRNA levels after $1 \mathrm{~h}$ and $4 \mathrm{~h}$. ACHN cells expressed ECE-1b and ECE-1c, but not the ECE-1a isoform of this peptidase. RT-PCR for the combined isoforms ECE- $1 \mathrm{~b} / \mathrm{c} / \mathrm{d}$ showed $\mathrm{TNF} \alpha$ to increase mRNA levels at $2 \mathrm{~h}$ and $4 \mathrm{~h}$. Forskolin had no effect on ECE-1b/c/d mRNA levels. Thus, expression of ET-2 and ECE-1b/c/d mRNAs in ACHN cells do not display the co-ordinated regulation observed with typical peptide prohormone processing enzymes and their substrates. Fournal of Molecular Endocrinology (2000) 24, 273-283

\section{INTRODUCTION}

The endothelins (ET-1, ET-2 and ET-3) are a family of 21 amino acid vasoconstrictor peptides first identified in 1988 (Yanagisawa et al. 1988, Inoue et al. 1989). All three endothelins follow a similar pattern of biosynthesis with initial synthesis as precursor proteins ( $\approx 200$ amino acid residues) which undergo selective proteolysis to yield the biologically inactive intermediates called big endothelins (Yanagisawa et al. 1988, Bloch et al. 1989, Ohkubo et al. 1990). The active endothelins are generated by hydrolysis of the $\operatorname{Trp}^{21}-\mathrm{Val}^{22}$ bond in big ET-1 and big ET-2, or Trp ${ }^{21}-\mathrm{Ile}^{22}$ in big ET-3 (Brooks \& Ergul 1998). This cleavage is unique to the endothelins and hence the role of a specific endothelin-converting enzyme (ECE) was proposed (Yanagisawa et al. 1988). Whether the hydrolysis of each of the three big ET molecules is dependent on a distinct ECE has yet to be elucidated.

Purification and molecular cloning of a phosphoramidon-sensitive ECE, named ECE-1, has been described (Schmidt et al. 1994, Shimada et al . 1994, Xu et al. 1994, Turner et al. 1998). There are at least four distinct isoforms of this enzyme encoded by the same gene but regulated by different promoters. Termed ECE-1a, ECE-1b, ECE-1c and ECE-1d, the four isoforms differ only in their $\mathrm{N}$-terminal cytoplasmic regions (Valdenaire et al. 
1995, Schweizer et al. 1997, Valdenaire et al. 1999). ECE-1 is a highly glycosylated type II transmembrane protease with a neutral $\mathrm{pH}$ optimum. It has structural and sequence homology to neutral endopeptidase (E.C.24-11) and to Kell blood group protein (Turner \& Tanzawa 1997). ECE-1 mRNA has been demonstrated in ovary, heart, placenta, pancreas, adrenal and lung, and has been localised to vascular endothelial cells and some secretory cells (Schmidt et al. 1994, Shimada et al. 1994, Xu et al. 1994, Takahashi et al. 1995). Previous studies have shown that the human renal adenocarcinoma cell line $(\mathrm{ACHN})$ synthesises ET-2 but not ET-1 or ET-3 (Ohkubo et al. 1990 Yorimitsu et al. 1992). ECE-1b was cloned from ACHN cells (Yorimitsu et al. 1995), but a number of studies have reported big ET-2 to be hydrolysed inefficiently by isoforms of ECE-1 (Schmidt et al. 1994, Shimada et al. 1994, $\mathrm{Xu}$ et al. 1994), hence casting doubts on its role in ET-2 synthesis.

Cytokines, such as tumour necrosis factor- $\alpha$ $(\mathrm{TNF} \alpha)$, cause a marked induction of ET-1 synthesis in endothelial cells by increasing the steady-state levels of ET-1 mRNA (Marsden \& Brenner 1992). In contrast to ET-1, the intracellular signalling mechanisms inducing the expression and synthesis of ET-2 have not been extensively investigated. Here, we show that ET-2 synthesis in ACHN cells is regulated by TNF $\alpha$ and cAMP. To determine the relationship between the expression of ET-2 and ECE-1 in ACHN cells, the levels of their mRNAs were compared by semi-quantitative RT-PCR after treatment with forskolin and TNFa.

\section{MATERIALS AND METHODS}

\section{Cell culture}

The human cell lines ACHN (ECACC No. 88100508), A549 (ECACC No. 86012804) and U937 (ECACC No. 85011440) were obtained from the European Collection of Animal Cell Cultures (ECACC; Salisbury, Wilts, UK). The human endothelial cell line EA.hy 926 was provided by Dr C-J S Edgell (Edgell et al. 1983). ACHN, A549 and EA.hy 926 were grown in Dulbecco's modified Eagle's medium (DMEM) supplemented with $10 \%$ foetal calf serum, penicillin $(100 \mathrm{U} / \mathrm{ml})$, streptomycin $(100 \mu \mathrm{g} / \mathrm{ml})$ and amphotericin $(2.5 \mu \mathrm{g} / \mathrm{ml})$ at $37^{\circ} \mathrm{C}$ in a humidified $\mathrm{CO}_{2}$ incubator $(95 \%$ air, $5 \%$ $\mathrm{CO}_{2}$ ). U937 were grown in RPMI 1640 medium with the same supplements and conditions. Medium for EA.hy 926 cells also included the HAT supplements $(100 \mu \mathrm{M}$ hypoxanthine, $0 \cdot 4 \mu \mathrm{M}$ aminopterin, $16 \mu \mathrm{M}$ thymidine; Sigma, St Louis, MO, USA).

\section{ET-2 release experiments}

ACHN cells were grown to confluence on $6 \times 9.5 \mathrm{~cm}^{2}$ well plates. Cells were incubated for $6 \mathrm{~h}$ with $2 \mathrm{ml}$ serum-free DMEM containing the agents to be tested. Forskolin and dibutyryl cAMP were from Sigma. Human $\mathrm{TNF} \alpha$ was from R \& D Systems (Minneapolis, MN, USA). Initial experiments studied the effect on ET-2 synthesis of phosphoramidon (0.03-300 $\mu \mathrm{M}$; Peptide Institute, Osaka, Japan). Because low concentrations of phosphoramidon increased the stability of the released ET-2 without affecting synthesis, $0 \cdot 3 \mu \mathrm{M}$ was included in the medium for all subsequent experiments. To demonstrate that the test agents were free of cytotoxic effects, mitochondrial dehydrogenase activity was measured at the end of the treatment period by conversion of MTT (Sigma) to formazan. In initial time-course experiments, ACHN cells grown on $9.5 \mathrm{~cm}^{2}$ plates were treated with $\mathrm{TNF} \alpha(3 \mathrm{ng} / \mathrm{ml})$, forskolin $(30 \mu \mathrm{M})$ or the combination, for periods of $0 \cdot 5-4 \mathrm{~h}$. Conditioned media were collected for ET-2 measurement and the cells were harvested in RNAzol B (Biogenesis, Poole, Dorset, UK) for subsequent extraction of RNA. However, as levels of secreted ET-2 during short time-periods were low, later time-course studies were performed using ACHN cells grown on $75 \mathrm{~cm}^{2}$ flasks.

\section{Measurement of secreted ET-2}

Conditioned media were acidified with glacial acetic acid and extracted using disposable Extra-Sep $\mathrm{C}_{18}$ columns (Lida, Kenosha, WI, USA), eluted with $80 \%$ acetonitrile containing $0 \cdot 1 \%$ trifluoroacetic acid, and dried down at $50{ }^{\circ} \mathrm{C}$ under a stream of nitrogen (Corder et al. 1995). ET-2 was measured either by RIA using a rabbit antiserum raised against the common C-terminal sequence of the endothelins, His-Leu-Asp-Ile-Ile-Trp (Corder et al. 1995), with ${ }^{125}$ I-ET-1 as tracer and ET-2 as standard, or by using an ET-1 ELISA (R \& D Systems). The crossreactivity of ET-2 relative to ET-1 was $100 \%$ in both assays.

\section{RT-PCR}

Total cellular RNA was extracted using RNAzol B. RT-PCR was performed using Access RT-PCR reagents (Promega, Madison, WI, USA) according to the instructions supplied. PCR primers were initially designed for preproET-2, ECE-1a, ECE1b, glyceraldehyde-3-phosphate dehydrogenase (GAPDH), type-1 TNF receptors (TNFR-1) and TNFR-2 by reference to the respective human cDNA sequences (Table 1) (Ercolani 
TABLE 1. Oligonucleotide primers used for RT-PCR of preproET-2 (Ohkubo et al. 1990), ECE-1a, ECE-1b/c/d, ECE-1b, ECE-1c (Valdenaire et al. 1995, Schweizer et al. 1997), GADPH (Ercolani et al. 1988), TNFR-1 (Loetscher et al. 1990) and TNFR-2 (Beltinger et al. 1996)

\begin{tabular}{|c|c|c|c|c|c|c|}
\hline & $\begin{array}{l}\text { Predicted PCR } \\
\text { product size }\end{array}$ & Sequence & $\begin{array}{l}\text { Sense/ } \\
\text { antisense }\end{array}$ & $\begin{array}{l}\text { Annealing } \\
\text { time/temp. }\end{array}$ & $\begin{array}{l}\text { Extension } \\
\text { time/temp. }\end{array}$ & Cycles \\
\hline \multicolumn{7}{|l|}{ Gene } \\
\hline preproET-2 & 309 & $\begin{array}{l}\text { 5'-AGCCAGCGTCCTCATCTCAT-3' } \\
\text { 5'-TGCCAGTCTGGAACACGTCT-3' }\end{array}$ & $\begin{array}{l}\mathrm{S} \\
\mathrm{A}\end{array}$ & $0 \cdot 5 / 60$ & $1 / 72$ & 25 \\
\hline ECE-1a & 734 & 5'-CTGAGACAGGAGGCAGC-3' & $\mathrm{S}$ & $1 / 65$ & $2 / 72$ & 40 \\
\hline $\mathrm{ECE}-1 \mathrm{~b} / \mathrm{c} / \mathrm{d}$ & 699 & 5'-GATGTCGACGTACAAGC-3' & $\mathrm{S}$ & $1 / 60$ & $2 / 68$ & 25 \\
\hline ECE-1b specific & 715 & 5'-TGCTGTCGGCGCTGGGGATG-3' & $\mathrm{S}$ & $1 / 62$ & $2 / 68$ & 24 \\
\hline ECE-1c specific & 715 & 5'-GGAGCACGCGAGCTATGATG-3' & $\mathrm{S}$ & $1 / 62$ & $2 / 68$ & 24 \\
\hline ECE-1 common & & 5'-CTGTTGGAGTTCTTGGAATC-3' & A & & & \\
\hline \multirow[t]{2}{*}{ GAPDH } & \multirow[t]{2}{*}{859} & 5'-TGAAGGTCGGAGTCAACGGA-3' & $\mathrm{S}$ & \multirow[t]{2}{*}{$1 / 65$} & \multirow[t]{2}{*}{$2 / 72$} & \multirow[t]{2}{*}{20} \\
\hline & & 5'-GTGTCGCTGTTGAAGTCAGA-3' & A & & & \\
\hline \multirow[t]{2}{*}{ TNFR-1 } & \multirow[t]{2}{*}{495} & 5'-ACCTCCAGCTCCACCTATAC-3' & $\mathrm{S}$ & \multirow[t]{2}{*}{$1 / 62$} & \multirow[t]{2}{*}{$2 / 72$} & \multirow[t]{2}{*}{40} \\
\hline & & 5'-GCAGCCTCATCTGAGAAGAC-3' & A & & & \\
\hline \multirow[t]{2}{*}{ TNFR-2 } & \multirow[t]{2}{*}{473} & 5'-GACTGAGTCCTCGTAGCCAT-3' & $\mathrm{S}$ & \multirow[t]{2}{*}{$1 / 62$} & \multirow[t]{2}{*}{$2 / 72$} & \multirow[t]{2}{*}{40} \\
\hline & & 5'-CAAGCTCAAGTCCAGTGGAA-3' & $\mathrm{A}$ & & & \\
\hline
\end{tabular}

Each PCR reaction used a $94{ }^{\circ} \mathrm{C}$ denaturation for $0.5 \mathrm{~min}$ at the start of each cycle followed by the indicated annealing and extension times (min) and temperatures (temp.; ${ }^{\circ} \mathrm{C}$ ). At the completion of the indicated number of cycles a final extension for 7 min at $72{ }^{\circ} \mathrm{C}$ was performed for each reaction.

et al. 1988, Loetscher et al. 1990, Ohkubo et al. 1990, Valdenaire et al. 1995, Beltinger et al. 1996). Primers were synthesised by Eurogentec (Abingdon, Oxon, UK). Following publication of cDNA sequences for ECE-1c, and more recently ECE-1d, it became clear that the sense primer used for comparative measurements of ECE-1b and preproET-2 mRNA levels was homologous with the corresponding sequences of ECE-1c and ECE-1d mRNAs (Schweizer et al. 1997, Valdenaire et al. 1999). Therefore, this primer is referred to as ECE-1b/c/d. Additional sense primers were designed based on the specific gene sequences of human ECE-1b and ECE-1c (Schweizer et al. 1997). For the design of primers for a human preproET-2 PCR product, reference was made to the sequence of the rat preproET-2 gene (accession numbers U59510, U64946-49) to obtain primers that should be intron spanning for the human sequence. DNA contamination did not contribute to the PCR products obtained. This was confirmed by performing PCR, with and without RT, and by using a sample contaminated with DNA (data not shown). The preproET-2 primers were not homologous with human preproET-1 or preproET-3 cDNA sequences. Except for TNFR-2, all other primer sequences were intron-spanning.

Oligo-d $\mathrm{T}_{15}(1 \mu \mathrm{M}$ final concentration $)$ was added to all ECE-1b/c/d, TNFR-1 and TNFR-2 PCR reactions to prime the RT reaction. For each reaction total RNA was reverse transcribed using avian myeloblastosis virus reverse transcriptase at $48^{\circ} \mathrm{C}$ for $45 \mathrm{~min}$. Preliminary experiments were conducted for preproET-2, ECE-1, and GAPDH to define semi-quantitative PCR conditions. This was done by using 50-200 ng total RNA to determine the PCR amplification conditions required to give a yield of PCR product which was proportional to the quantity of RNA template. Subsequent studies used $100 \mathrm{ng}$ total RNA per reaction. Optimised cycling conditions for each gene in a total volume of $50 \mu \mathrm{l}$ are shown in Table 1 . PCR products $(10 \mu \mathrm{l}$ per lane) were electrophoresed in $1 \%$ agarose gels at $120 \mathrm{~V}$, and stained with ethidium bromide. Band intensities were quantified with a Gel Doc 1000 system using Molecular Analyst software (Bio-Rad, Hercules, CA, USA). For each sample the yield of PCR products for preproET-2 or ECE-1b/c/d mRNA was expressed relative to that obtained for GAPDH mRNA.

\section{Characterisation of TNF receptors in ACHN cells}

To complement RT-PCR identification of TNF receptor mRNA in ACHN cells, the roles of specific TNF receptors in the induction of ET-2 synthesis were investigated by using receptor-selective mutants of human TNFa. Studies of ${ }^{125} \mathrm{I}-\mathrm{TNF} \alpha$ binding to ACHN cells $\left(24 \times 2 \mathrm{~cm}^{2}\right.$ well plates $)$ were also performed for comparison. Binding of ${ }^{125} \mathrm{I}-\mathrm{TNF} \alpha$ was determined in the presence of receptor selective $\mathrm{TNF} \alpha$ mutants or blocking antibodies. The effects of receptor selective TNF $\alpha$ mutants on ${ }^{125} \mathrm{I}-\mathrm{TNF} \alpha$ binding were studied using binding medium (DMEM with $2.5 \mathrm{mM}$ Hepes and $2.5 \%$ bovine serum albumin (BSA)) containing human TNFa (R \& D Systems), the TNFR-1 
selective mutant, R32W-S86T, or the TNFR-2 selective mutant, D143N-A145R (0.5-2000 ng/ml) (Hoffman-La Roche Ltd, Basel, Switzerland) (Loetscher et al. 1993). For studies of blocking antibodies, binding medium containing anti-human TNFR-1 or TNFR-2 neutralising monoclonal antibodies $(0 \cdot 5-100 \mathrm{ng} / \mathrm{ml})$ (R \& D Systems) was incubated for $50 \mathrm{~min}$ at $37^{\circ} \mathrm{C}$. After pretreatment with the neutralising antibodies, or immediately after the addition of $\mathrm{TNF} \alpha$ or $\mathrm{TNF} \alpha$ mutants to cells, ${ }^{125} \mathrm{I}$-TNF $\alpha$ was added to each well to give a total incubation volume of $0 \cdot 2 \mathrm{ml} .{ }^{125} \mathrm{I}-\mathrm{TNF} \alpha$ was trimeric TNFa labelled with ${ }^{125}$ I-Bolton and Hunter reagent and chromatographically purified by gel filtration to ensure intact $\mathrm{TNF} \alpha$ trimer (Amersham International plc, Amersham, Bucks, UK). The final concentration of ${ }^{125} \mathrm{I}-\mathrm{TNF} \alpha$ was $\approx 300 \mathrm{pM}$ expressed as $17 \cdot 5 \mathrm{kDa}$ TNF $\alpha$ monomer, with a specific activity of $10.4 \mathrm{MBq} / \mathrm{nmol} \mathrm{TNF} \alpha$ monomer. After incubation of ${ }^{125} \mathrm{I}-\mathrm{TNF} \alpha$ at $37^{\circ} \mathrm{C}$ for $2.5 \mathrm{~h}$, cells were washed three times with phosphate-buffered saline containing $0 \cdot 1 \%$ BSA $(1 \mathrm{ml}$ per well), and then lysed with $0 \cdot 1 \mathrm{M} \mathrm{NaOH}$, $0 \cdot 5 \%$ SDS $(200 \mu \mathrm{l}$ per well) for measurement of bound radioactivity.

\section{Analysis of results}

All results are expressed as means \pm S.E.M. and statistical comparisons were made by analysis of variance with Fisher's LSD test.

\section{RESULTS}

\section{Effect of phosphoramidon on ET-2 synthesis}

Phosphoramidon $(0 \cdot 03-3 \mu \mathrm{M})$ caused a $40-55 \%$ increase in the amount of ET-2 accumulating in the conditioned media over $24 \mathrm{~h}(P<0 \cdot 01$, Fig. 1). Higher concentrations resulted in a concentrationdependent reduction in ET-2 synthesis. Based on the maximum level of $\mathrm{ET}-2$ release, the $\mathrm{IC}_{50}$ for inhibition of ET-2 synthesis by phosphoramidon was $\cong 11 \mu \mathrm{M}$, which is 17 -fold less than that for inhibition of ET-1 synthesis by A549 cells $\left(\mathrm{IC}_{50}\right.$ $\cong 190 \mu \mathrm{M}$; Fig. 1) (Corder et al. 1995).

\section{Stimulatory effects of TNF $\alpha$, forskolin and dibutyryl cAMP on ET- 2 release}

Treatment of ACHN cells for $6 \mathrm{~h}$ with $\mathrm{TNF} \alpha$ $(0 \cdot 1-100 \mathrm{ng} / \mathrm{ml})$, forskolin $(0 \cdot 1-30 \mu \mathrm{M})$, or dibutyryl cAMP $(10-1000 \mu \mathrm{M})$ caused concentrationdependent increases in ET-2 release (Fig. 2). The threshold concentration for $\mathrm{TNF} \alpha$ was $0 \cdot 3 \mathrm{ng} / \mathrm{ml}$

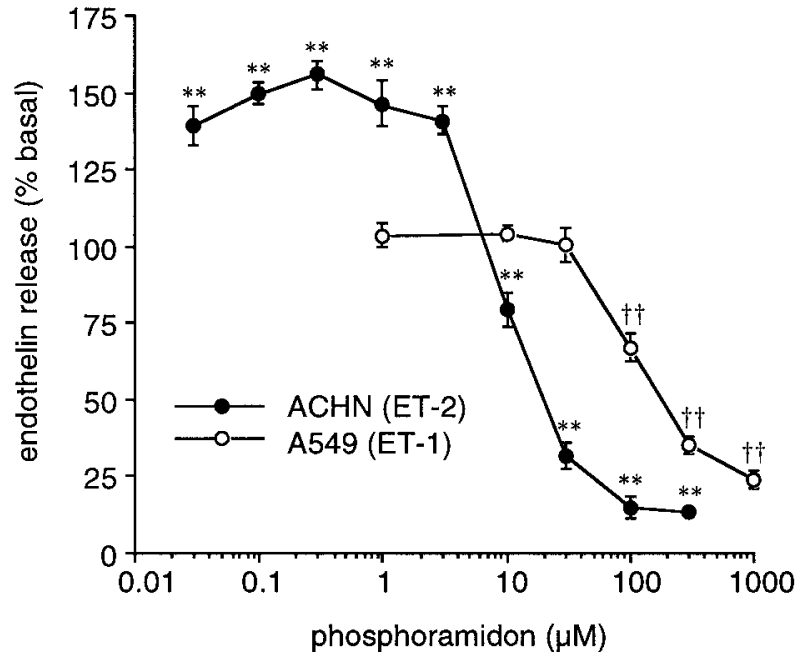

FIGURE 1. Effect of phosphoramidon on ET-1 and ET-2 secretion from A549 and ACHN cells respectively. Results are from three to five separate experiments. Basal release over $24 \mathrm{~h}$ was $41 \pm 4 \mathrm{fmol} \mathrm{ET}-1 / \mathrm{cm}^{2}$ for

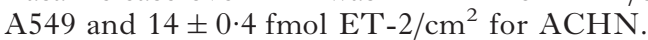

$\uparrow \uparrow P<0 \cdot 01, * * P<0 \cdot 01$ compared with basal release of ET-1 and ET-2 respectively.

and the maximum response was obtained at $3 \mathrm{ng} / \mathrm{ml}$, which represented an almost twofold increase compared with basal release $(P<0 \cdot 001$; Fig. 2). Forskolin $(30 \mu \mathrm{M})$ increased ET-2 secretion by $316 \pm 56 \%$ (Fig. 2). Higher concentrations showed cytotoxicity. The effect of dibutyryl cAMP confirmed that forskolin induced ET-2 synthesis via a cAMP-dependent mechanism.

Combination of forskolin $(30 \mu \mathrm{M})$ with an excess of $\mathrm{TNF} \alpha(100 \mathrm{ng} / \mathrm{ml})$ produced a significantly greater increase in ET-2 secretion $(297 \pm 18 \%$ higher than basal release, $P<0 \cdot 01)$ than either agent alone (increases for forskolin and $\mathrm{TNF} \alpha$ were $202 \pm 11 \%$ and $80 \pm 12 \%$ above basal respectively). Dibutyryl cAMP $(500 \mu \mathrm{M})$ combined with TNF $\alpha$ $(3 \mathrm{ng} / \mathrm{ml})$ also produced a significantly greater increase in ET-2 secretion $(326 \pm 26 \%$ greater than basal release, $P<0 \cdot 01)$ than treatment with dibutyryl cAMP alone (226 $\pm 20 \%$ above basal release).

\section{Comparison of ET-2 synthesis with levels of preproET-2 mRNA}

Basal release of ET-2 increased in a time-dependent manner over the 4-h study period (Fig. 3a). After $1 \mathrm{~h}$, ET-2 secretion was increased by $50 \%$ by forskolin $\quad(30 \mu \mathrm{M}) \quad(P<0 \cdot 05)$. However, TNF $\alpha$ $(3 \mathrm{ng} / \mathrm{ml})$ only induced a significant increase in ET-2 secretion after 4 -h stimulation $(P<0 \cdot 01$; Fig. 3a). Combination of the two agents produced 

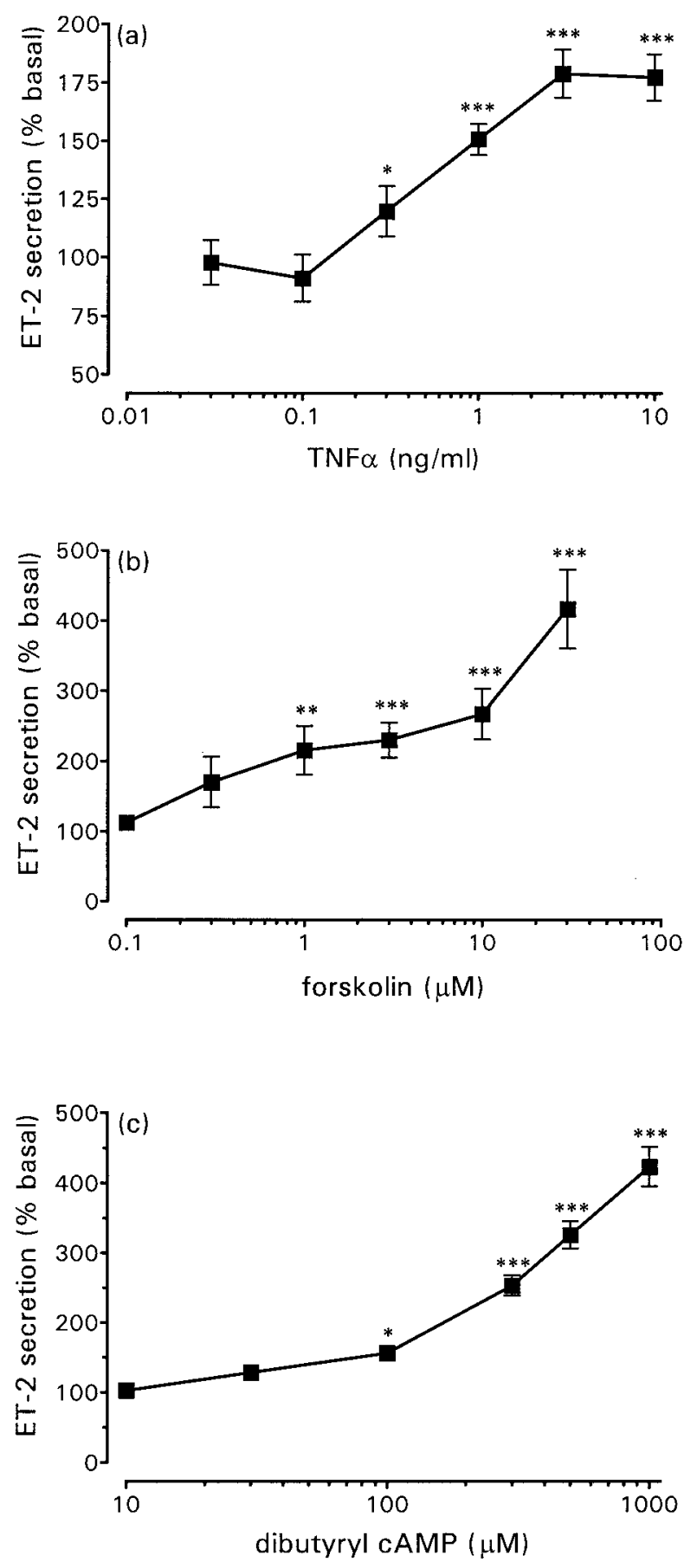

FIGURE 2. Effect of (a) TNF $\alpha$, (b) forskolin and (c) dibutyryl cAMP on ET-2 release from ACHN cells. ACHN cells were treated with (a) $\mathrm{TNF} \alpha$, (b) forskolin, or (c) dibutyryl cAMP for $6 \mathrm{~h}$. Results are triplicate evaluations from three to five separate experiments. Mean basal release of ET-2 was (a) $22 \cdot 5 \pm 2 \cdot 8$, (b) $28 \cdot 9 \pm 1 \cdot 3$ and (c) $48 \cdot 0 \pm 4 \cdot 3 \mathrm{fmol} / 9 \cdot 5 \mathrm{~cm}^{2}$ well $/ 6 \mathrm{~h}$. $* P<0 \cdot 05, * * P<0 \cdot 01, * * * P<0 \cdot 001$ compared with basal release. significantly higher levels of ET-2 in the medium at $0 \cdot 5 \mathrm{~h}, 2 \mathrm{~h}$ and $4 \mathrm{~h}$ compared with the corresponding basal secretion. At $4 \mathrm{~h}, \mathrm{ET}-2$ levels with the combined treatments were greater than with either forskolin or TNF $\alpha$ alone $(P<0 \cdot 001)$.

Time-dependent effects of TNF $\alpha(3 \mathrm{ng} / \mathrm{ml})$ and forskolin $(30 \mu \mathrm{M})$ on levels of $\mathrm{mRNA}$ for preproET-2 were investigated using semiquantitative RT-PCR. A single PCR product of the correct size was obtained for preproET-2. Basal levels of preproET-2 mRNA did not change over the 4-h study period (Fig. 3b). Treatment with $\mathrm{TNF} \alpha$, forskolin or the combination for $1 \mathrm{~h}$ caused increases of approximately $80 \%$ in the levels of preproET-2 mRNA (expressed as preproET-2/ GAPDH ratios) (Figs $3 \mathrm{~b}$ and $4 \mathrm{c} ; P<0.05$ ). This paralleled small changes in ET-2 synthesis over this period. The largest increase in ET-2 release was observed at $4 \mathrm{~h}$, which therefore reflects the increased biosynthesis over the preceding $2 \mathrm{~h}$. In agreement with this, the levels of preproET$2 \mathrm{mRNA}$ at $2 \mathrm{~h}$ with $\mathrm{TNF} \alpha$ alone were approximately twofold higher than control $(P<0 \cdot 05)$, and in combination with forskolin were elevated more than threefold $(P<0 \cdot 001$; Fig. 3b). By $4 \mathrm{~h}$, levels of preproET-2 mRNA in the presence of TNF $\alpha$ had declined to those of untreated control cells. With forskolin treatment, levels of preproET-2 mRNA at $2 \mathrm{~h}$ were not different from control, but were raised by $4 \mathrm{~h}$, supporting an increase in ET-2 synthesis between 2 and $4 \mathrm{~h}(P<0 \cdot 001)$.

\section{Expression of ECE-1 mRNAs}

Initial experiments investigated which isoforms of ECE-1 could be detected in ACHN cells by RT-PCR. ECE-1a was undetectable after 40 cycles (over-amplified conditions) using a specific ECE-1a sense primer and a common ECE-1 antisense primer (Fig. 4a). The same cycling conditions yielded a PCR product of the correct size from human endothelial cell line EA.hy 926 (Fig. 4a). By comparison, ECE-1b/c/d was readily detected in both cell lines using 25 cycles (Fig. 4b).

In contrast to preproET-2 mRNA levels, levels of ECE-1b/c/d mRNA did not display the same large increases at $2 \mathrm{~h}$ when the phase of maximum ET-2 synthesis appears to be initiated (Fig. 3c). At $4 \mathrm{~h}$, TNF $\alpha$-stimulated cells showed increased levels of ECE-1b/c/d mRNA both alone and combined with forskolin $(P<0 \cdot 05 ;$ Fig. 3c). Treatment with forskolin did not alter ECE-1b/c/d mRNA expression during the 4-h study period (Fig. 3c).

To determine whether ACHN cells express both ECE-1b and ECE-1c mRNAs, RT-PCR was performed using isoform specific primers. While 

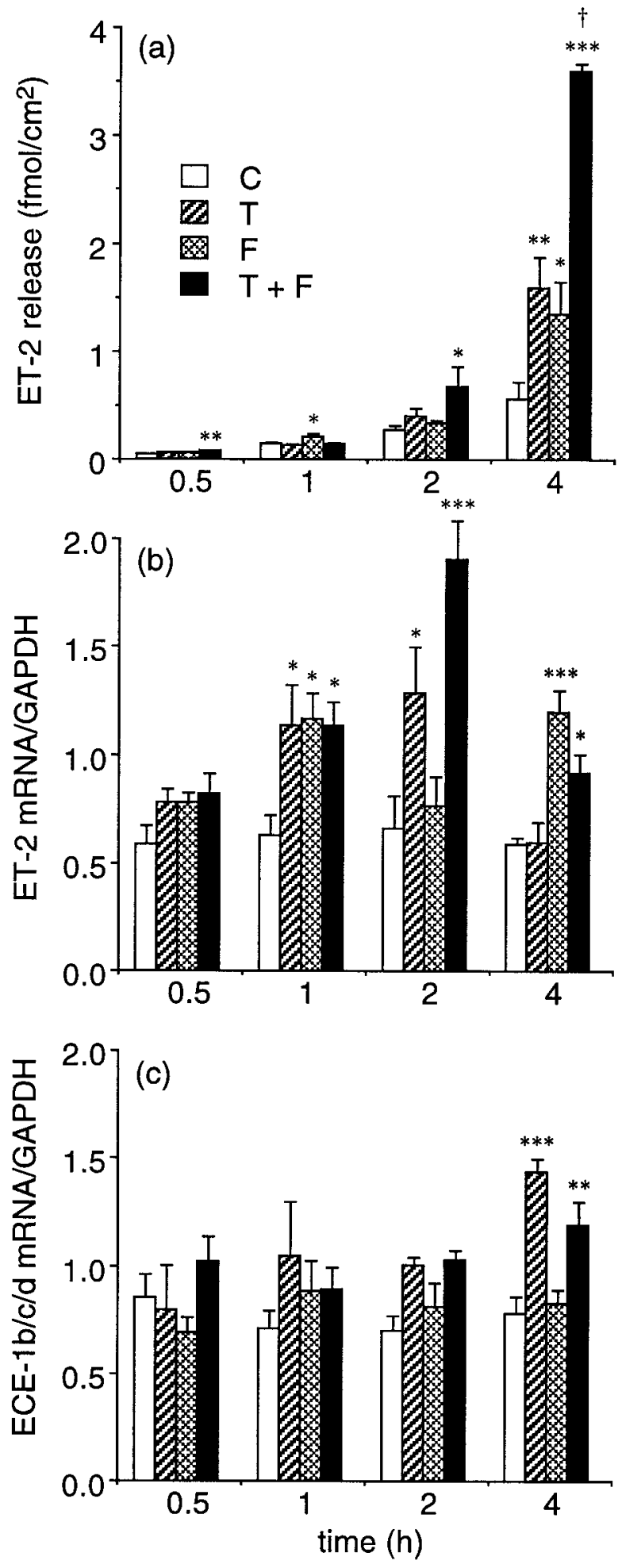

approximately equal amounts of $\mathrm{ECE}-1 \mathrm{~b}$ and ECE-1c mRNA were present in ACHN cells (Fig. 4b), EA.hy 926 cells showed similar amounts of ECE-1c mRNA, but ECE-1b mRNA was virtually undetectable (Fig. 4b). As preproET-2 mRNA levels were increased by TNF $\alpha$ and forskolin at $1 \mathrm{~h}$ (Fig. 3b), the effects of TNF $\alpha$ and forskolin on ECE-1b and ECE-1c mRNA levels were re-evaluated at $1 \mathrm{~h}$ using the isoform specific primers. Consistent with earlier experiments, $\mathrm{TNF} \alpha$ or forskolin increased preproET-2 mRNA levels by approximately $75 \%(P<0 \cdot 01, n=3$, data not shown), but neither ECE-1b nor ECE-1c mRNA levels were altered by these treatments (data not shown, $n=3)$.

\section{Characterisation of TNF receptors regulating ET-2 release}

To investigate the expression of TNFR-1 and TNFR-2 mRNA in ACHN cells, total RNA was subjected to RT-PCR using primers specific for TNFR-1 or TNFR-2. The human A549 and U937 cell lines express TNFR-1 mRNA and TNFR-2 mRNA respectively (Iwamoto et al. 1994, Shimomoto et al. 1995). Total RNA extracted from these cells was subjected to RT-PCR in parallel with ACHN samples. A PCR product of the correct size was obtained in each positive control (Fig. 4d and e). However, in ACHN cells, only TNFR-1 mRNA was expressed and TNFR-2 mRNA was undetectable (Fig. 4d and e).

To determine the roles of the TNFR-1 and TNFR-2 receptors in TNF $\alpha$-mediated ET-2 release, ACHN cells were stimulated with the TNFR-1 selective mutant, R32W-S86T $(0 \cdot 2-20 \mathrm{ng} /$ $\mathrm{ml})$, the TNFR-2 selective mutant D143N-A145R $(0 \cdot 6-200 \mathrm{ng} / \mathrm{ml})$ or both $(0 \cdot 2-20 \mathrm{ng} / \mathrm{ml})$ for $6 \mathrm{~h}$. The TNFR-1 selective mutant, R32W-S86T, increased ET-2 secretion in a concentrationdependent manner (Fig. 5a). The maximal increase in release $(89 \pm 14 \%$ above basal levels; $P<0 \cdot 001)$

FIGURE 3. Time-dependent changes in (a) ET-2 secretion, (b) preproET-2 and (c) ECE-1b/c/d mRNA levels after treatment of ACHN cells with forskolin, TNF $\alpha$ or the combination. ACHN cells on $75 \mathrm{~cm}^{2}$ flasks or $6 \times 9.5 \mathrm{~cm}^{2}$ well plates were treated with $30 \mu \mathrm{M}$ forskolin (F), $3 \mathrm{ng} / \mathrm{ml} \mathrm{TNF} \alpha(\mathrm{T})$ or the combination (T+F) for 0.5-4 h. (b) PreproET-2 and (c) ECE-1b/c/d mRNA levels were measured by RT-PCR and are expressed relative to GAPDH values. Data are from four separate experiments. ${ }^{*} P<0 \cdot 05,{ }^{* *} P<0 \cdot 01$, $* * * P<0 \cdot 001$ compared with corresponding control (C) levels, $\uparrow P<0 \cdot 001$ compared with 4 -h treatment with $\mathrm{TNF} \alpha$ or forskolin alone. 
(a) ECE-1a

(b) ECE-1b/c/d ECE-1b ECE-1c
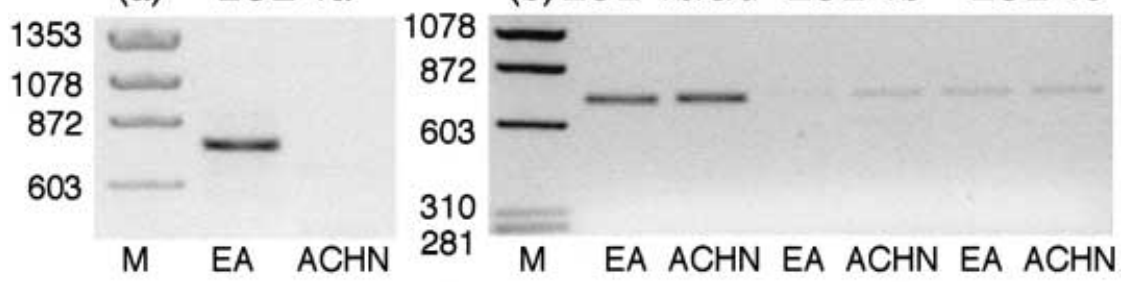

(c) preproET-2
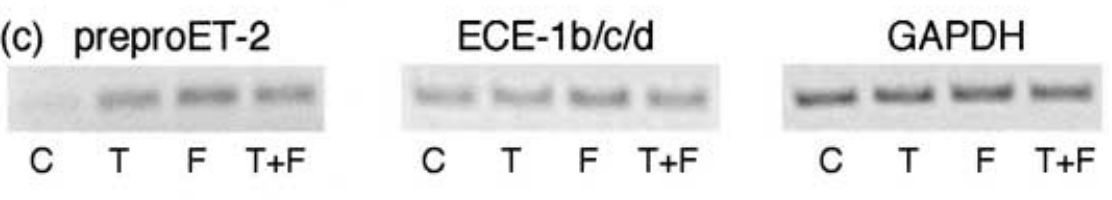

\section{(d) TNFR-1}

310

281
872

603
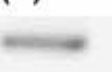

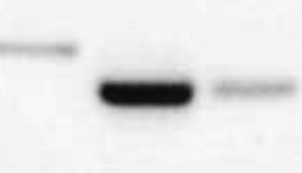

\section{A549 ACHN}

(e) TNFR-2

872

603

310

281

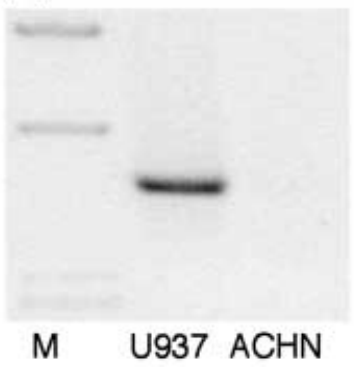

FIGURE 4. Evaluation of mRNA expression in ACHN cells for (a) ECE-1a, (b) ECE-1b/c/d, ECE-1b and ECE-1c, (c) preproET-2, ECE-1b/c/d and GAPDH, (d) TNFR-1 and (e) TNFR-2. RNA samples from ACHN cells were subjected to RT-PCR using sense primers for (a) ECE-1a or (b) ECE-1b/c/d, ECE-1b and ECE-1c with a common ECE-1 antisense primer, and compared with EA.hy 926 cells. (c) This shows representative PCR products for preproET-2, ECE-1b/c/d and GAPDH mRNA after 1-h treatment of ACHN with TNF $\alpha$ (T), forskolin $(\mathrm{F})$ or the combination $(\mathrm{T}+\mathrm{F})$ compared with control (C).

RT-PCR for TNF receptor mRNA using primers for TNFR-1 (d) and

TNFR-2 (e) - comparison of ACHN with samples from A549 and U937 cell lines as sources of TNFR-1 and TNFR-2 mRNA. RT-PCR conditions were semi-quantitative in (b) and (c), and over-amplified (40 cycles) in (a), (d) and (e). M; molecular size markers $(\varphi \mathrm{X} 174 \mathrm{RF}$ DNA HaeIII fragments; Gibco (Paisley, UK)).

was comparable to native TNFa (Figs 2a and 5a). Combination of the two mutants did not produce a greater effect than the TNFR-1 selective mutant alone (Fig. 5a). The TNFR-2 selective mutant D143N-A145R alone had no significant effect on ET-2 secretion at any concentration tested (Fig. 5a).

Studies of ${ }^{125} \mathrm{I}-\mathrm{TNF} \alpha$ binding to ACHN cells showed wild-type TNF $\alpha$ and the TNFR-1 selective mutant, R32W-S86T, caused a concentrationdependent inhibition of binding (Fig. $5 \mathrm{~b}$; $\mathrm{IC}_{50}$ values $\cong 12$ and $29 \mathrm{ng} / \mathrm{ml}$ respectively). The higher $\mathrm{IC}_{50}$ value obtained for R32W-S86T is consistent with the twofold lower binding affinity of this mutant for the TNFR-1 receptor (Loetscher et al. 1993). The
TNFR-2 selective mutant, D143N-A145R, did not inhibit binding of ${ }^{125} \mathrm{I}-\mathrm{TNF} \alpha$. The role of the TNFR-1 receptor in binding ${ }^{125} \mathrm{I}-\mathrm{TNF} \alpha$ was also confirmed using receptor selective neutralising monoclonal antibodies (Table 2).

\section{DISCUSSION}

These results from ACHN cells have identified two distinct signalling pathways regulating preproET-2 synthesis - namely, a TNFR-1 receptor-linked induction and a cAMP-dependent mechanism. The increased levels of preproET-2 mRNA with TNF $\alpha$ 

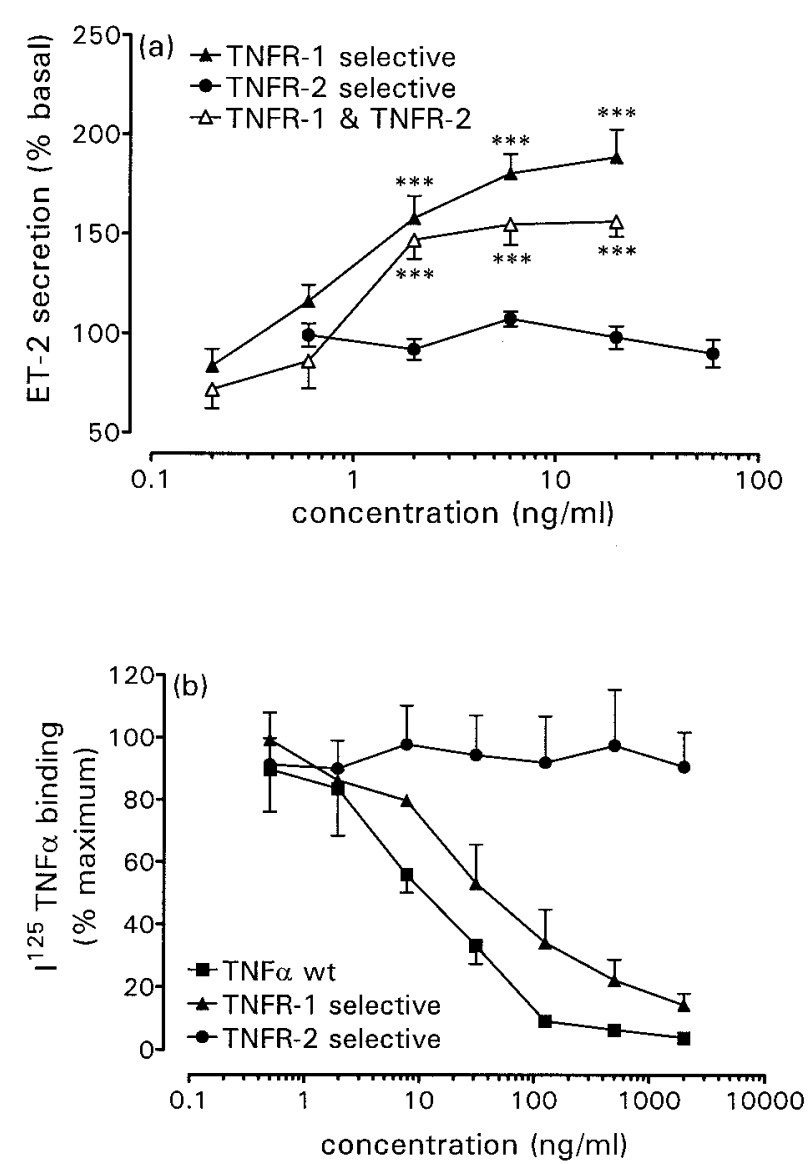

FIGURE 5. Effect of receptor selective TNF $\alpha$ mutants on ACHN cells (a) ET-2 release and (b) ${ }^{125} \mathrm{I}-\mathrm{TNF} \alpha$ binding. (a) ACHN cells were incubated with TNFR-1 selective TNF $\alpha$ mutant, R32W-S86T, TNFR-2 selective TNF $\alpha$ mutant, D143N-A145R (Loetscher et al. 1993), or both for $6 \mathrm{~h}$. Results are triplicate evaluations from four separate experiments. Mean basal release of ET-2 was $28 \cdot 9 \pm 1 \cdot 3 \mathrm{fmol} / 9 \cdot 5 \mathrm{~cm}^{2}$ well per $6 \mathrm{~h}$. $* * * P<0.001$ compared with basal release. (b) ACHN cells were treated with $\mathrm{TNF} \alpha$ (wt, wild type), or the receptor selective $\mathrm{TNF} \alpha$ mutants with ${ }^{125} \mathrm{I}-\mathrm{TNF} \alpha$ $(\approx 300 \mathrm{pM})$ for $2.5 \mathrm{~h}$ at $37^{\circ} \mathrm{C}$. Results are quadruplicate evaluations from three separate experiments. Mean maximum binding was $2671 \pm 176$ c.p.m. $/ 2 \mathrm{~cm}^{2}$ well.

and forskolin suggested that increased gene transcription underlies the induction of ET-2 synthesis by these stimuli. The synthesis of ET-2 in response to TNF $\alpha$ was significantly increased by combination with forskolin or dibutyryl cAMP, even though $\mathrm{TNF} \alpha$ was used at concentrations eliciting a maximal response. In addition, the time-course for changes in the levels of preproET-2 mRNA were different for TNF $\alpha$ and forskolin. Thus, it seems likely that TNF $\alpha$ and cAMP activate gene
TABLE 2. Inhibition of ${ }^{125} \mathrm{I}-\mathrm{TNF} \alpha$ binding by TNF receptor selective neutralising antibodies

\section{$\%$ Inhibition of ${ }^{125} \mathrm{I}-\mathrm{TNF} \alpha$ binding}

\begin{tabular}{ll}
$\begin{array}{l}\text { TNFR-1 neutralising } \\
\text { antibody }\end{array}$ & $\begin{array}{l}\text { TNFR-2 neutralising } \\
\text { antibody }\end{array}$ \\
\hline
\end{tabular}

$\begin{array}{lll}\begin{array}{l}\text { Antibody } \\ \text { concentration } \\ (\mathrm{ng} / \mathrm{ml})\end{array} & & \\ 0 \cdot 5 & 43 \cdot 3 \pm 4 \cdot 6 & 3 \cdot 0 \pm 8 \cdot 0 \\ 5 & 69 \cdot 0 \pm 3 \cdot 0 & -2 \cdot 4 \pm 10 \cdot 2 \\ 10 & 75 \cdot 9 \pm 2 \cdot 8 & -1 \cdot 4 \pm 7 \cdot 0 \\ 100 & 82 \cdot 9 \pm 1 \cdot 2 & 4 \cdot 7 \pm 12 \cdot 5\end{array}$

Results are quadruplicate evaluations from three separate experiments. Mean maximum binding was $2671 \pm 176$ c.p.m. $/ 2 \mathrm{~cm}^{2}$ well.

transcription through distinct mechanisms. Indeed, analysis of the promoter region of the human ET-2 gene (accession numbers E07665 and E07666) identifies a number of putative DNA-binding sequences for cAMP response element-binding protein and a variety of regulatory elements associated with TNF signalling, including NF- $\mathrm{KB}$. These results indicate some similarities with the regulation of the ET-1 gene as its synthesis is also induced by TNF $\alpha$ (Marsden \& Brenner 1992), but in contrast to preproET-2, forskolin suppresses preproET-1 expression (Malek et al. 1993).

The TNFR-1 receptor mediates many of the actions of TNFa (Heller \& Krönke 1994). In the studies described here, the effect of $\mathrm{TNF} \alpha$ was mimicked by a TNFR-1 selective TNF $\alpha$ mutant, but a TNFR-2 selective TNF $\alpha$ mutant was without effect. Similarly, studies with receptor selective $\mathrm{TNF} \alpha$ mutants and neutralising antibodies showed that binding of ${ }^{125} \mathrm{I}-\mathrm{TNF} \alpha$ to ACHN cells could be accounted for by the TNFR-1 receptor. Furthermore, TNFR-1 mRNA but not TNFR-2 mRNA was identified in ACHN cells, confirming that the TNFR-2 receptor is not involved in the induction of ET-2 synthesis by TNF $\alpha$ in these cells.

Studies of ET-1 biosynthesis have shown that processing of its precursor proendothelin-1, including the hydrolysis of big ET-1 by ECE to ET-1, occurs intracellularly prior to release (Harrison et al. 1993, 1995, Xu et al. 1994, Corder et al. 1995, Russell \& Davenport 1999). This bears a considerable similarity to the processing of many endocrine peptides. In agreement with studies of ET-1 synthesis (Corder et al. 1995), phosphoramidon inhibited ET-2 synthesis in a concentrationdependent manner. This effect was consistent with inhibition of the physiologically relevant ECE, as HPLC analysis of the conditioned medium followed 
by big ET-2 immunoassay of the HPLC fractions showed big ET-2 ${ }_{[1-38]}$ to accumulate in the conditioned media (data not shown). However, inhibition of ET-2 synthesis in ACHN cells displayed a greater than tenfold higher sensitivity to phosphoramidon compared with ET-1 synthesis by A549 cells. This suggests that different ECE isoforms are responsible for hydrolysis of big ET-1 and big ET-2.

Because efficient processing in secretory vesicles of endocrine peptide prohormones into bioactive peptides is dependent on the co-ordinated expression of the prohormone mRNA with the relevant processing enzymes (prohormone convertases, carboxypeptidase H) (Bloomquist et al. 1991, 1994, Schuppin \& Rhodes 1996), changes in levels of preproET-2 mRNA induced by TNF $\alpha$ or forskolin were compared with those of ECE-1b/c/d mRNA. This was performed to determine whether synthesis of ECE-1 correlated with that of preproET-2 in the manner of a typical processing enzyme to substrate relationship, which might be expected if ECE-1 has a role in big ET-2 cleavage in constitutive secretory vesicles of ACHN cells.

The time-course experiments with $\mathrm{TNF} \alpha$ and forskolin were performed before the distinction between the ECE-1b, ECE-1c and ECE-1d isoforms was established. The PCR product referred to as ECE $-1 \mathrm{~b} / \mathrm{c} / \mathrm{d}$ provided a measure of the combined levels of mRNA for these three ECE-1 isoforms as the DNA sequence corresponding to the sense primer is identical in ECE-1b, ECE-1c and ECE-1d (Valdenaire et al. 1999). Although the relative levels of each of these ECE-1 isoforms may have fluctuated, the amounts of the combined ECE-1b/c/d PCR product did not increase in parallel with those of preproET-2 mRNA during stimulation with either $\mathrm{TNF} \alpha$ or forskolin. After the description of the cDNA sequence for ECE-1c, the relationship between levels of preproET-2 mRNA and ECE-1b or ECE-1c was re-examined using specific primers, but again no parallels were observed, indicating that the regulation of these ECE-1 isoforms is not closely linked to the ET-2 gene. Comparisons of levels of ECE-1d mRNA with those of preproET-2 mRNA were not undertaken in these investigations.

The four isoforms of ECE-1 have been reported to have different locations when expressed in $\mathrm{CHO}$ cells or Madin-Darby canine kidney (MDCK) cells (Schweizer et al. 1997, Azarani et al. 1998, Brown et al. 1998, Schweizer et al. 1999, Valdenaire et al. 1999). ECE-1a is localised to the cell surface, ECE-1b is predominantly intracellular with a pattern of distribution comparable to the trans Golgi network (TGN), ECE-1c is found mainly on the cell surface with some associated with the TGN, and ECE-1d has been identified at intracellular sites and on the cell surface. Consistent with a cell surface localisation, both ECE-1a and ECE-1c isoforms expressed in CHO cells function as ectoenzymes with big ET-1 as the substrate (Xu et al. 1994, Takahashi et al. 1995). Based on available results describing the cellular localisation of the four isoforms in $\mathrm{CHO}$ and MDCK cells, it is not possible to determine which ECE-1 isoform, if any, is likely to be most important in the intracellular processing of the big ETs.

In endothelial cells, human ECE-1a (ECE-1 $\beta$ ), and rat and human ECE-1c (ECE-1 $\alpha)$ are localised, at least in part, to the plasma membrane ('Takahashi et al. 1995, Barnes et al. 1998, Brown et al. 1998, Russell et al. 1998). However, intracellular co-localisation of big ET-1 with ECE-1, including the ECE-1a and ECE-1c isoforms, has also been described (Barnes et al. 1998, Russell et al. 1998), with ECE-1 cycling between the cell surface and the TGN (Barnes et al. 1998). This suggests that ECE-1 processing of big ETs could occur during vesicle translocation from TGN to the plasma membrane, with the ECE-1 then undergoing recycling. However, because ET-1 synthesis still occurs in non-viable foetuses obtained on ECE-1 gene knockout (Yanagisawa et al. 1998), conclusive evidence for ECE-1 playing a role in ET-1 biosynthesis has yet to be described.

Although we cannot exclude the possibility that synthesis of ECE-1 protein may be sufficient to accommodate changes in the rate of ET-2 synthesis, based on the precedents of endocrine peptide processing, the absence of any relationship between ECE-1 expression and ET-2 synthesis casts doubts on its potential role as an intravesicle ECE. Moreover, when the many studies showing poor efficiency of big ET-2 hydrolysis by ECE-1 (Schmidt et al. 1994, Shimada et al. 1994, Xu et al. 1994) and the higher sensitivity to phosphoramidon of ET-2 synthesis compared with ET-1 are taken into account, it does not seem likely that ECE-1 plays a role in big ET-2 processing in ACHN cells.

\section{ACKNOWLEDGEMENTS}

We are indebted to Liz Wood for providing the cultured cells, Amersham International plc for the supply of ${ }^{125} \mathrm{I}-\mathrm{TNF} \alpha$, and Dr W Lesslauer and Dr H Loetscher of Hoffmann-La Roche Ltd for the $\mathrm{TNF} \alpha$ receptor selective mutants $\mathrm{R} 32 \mathrm{~W}-\mathrm{S} 86 \mathrm{~T}$ and 
D143N-A145R. We are grateful to the Institut de Recherches Internationales Servier for the financial support provided for this work. D M L was supported by a European Commission Marie Curie Research Grant (Training and Mobility of Researchers Programme).

\section{REFERENCES}

Azarani A, Boileau G \& Crine P 1998 Recombinant human endothelin-converting enzyme ECE-1b is located in an intracellular compartment when expressed in polarized Madin-Darby canine kidney cells. Biochemical fournal 333 439-448.

Barnes K, Brown C \& Turner AJ 1998 Endothelin-converting enzyme: ultrastructural localization and its recycling from the cell surface. Hypertension 31 3-9.

Beltinger CP, White PS, Maris JM, Sulman EP, Jensen SJ, LePaslier D, Stallard BJ, Goeddel DV, de Sauvage FJ \& Brodeur GM 1996 Physical mapping and genomic structure of the human TNFR2 gene. Genomics 35 94-100.

Bloch KD, Eddy RL, Shows TB \& Quertermous T 1989 cDNA cloning and chromosomal assignment of the gene encoding endothelin-3. Fournal of Biological Chemistry 264 18156-18161.

Bloomquist BT, Eipper BA \& Mains RE 1991 Prohormoneconverting enzymes: regulation and evaluation of function using antisense RNA. Molecular Endocrinology 5 2014-2024.

Bloomquist BT, Darlington DN, Mains RE \& Eipper BA 1994 RESP18, a novel endocrine secretory protein transcript, and four other transcripts are regulated in parallel with proopiomelanocortin in melanotropes. Fournal of Biological Chemistry 269 9113-9122.

Brooks C \& Ergul A 1998 Identification of amino acid residues in the $\mathrm{C}$-terminal tail of big endothelin-1 involved in processing to endothelin-1. Fournal of Molecular Endocrinology 21 307-315.

Brown CD, Barnes K \& Turner AJ 1998 Anti-peptide antibodies specific to rat endothelin-converting enzyme-1 isoforms reveal isoform localisation and expression. FEBS Letters 424 183-187.

Corder R, Khan N \& Harrison VJ 1995 A simple method for isolating human endothelin converting enzyme (ECE-1) free from contamination by neutral endopeptidase $24 \cdot 11$. Biochemical and Biophysical Research Communications 207 355-362.

Edgell CJ, McDonald CC \& Graham JB 1983 Permanent cell line expressing human factor VIII-related antigen established by hybridization. Proceedings of the National Academy of Sciences of the USA 80 3734-3737.

Ercolani L, Florence B, Denaro M \& Alexander M 1988 Isolation and complete sequence of a functional human glyceraldehyde-3-phosphate dehydrogenase gene. Fournal of Biological Chemistry 263 15335-15341.

Harrison VJ, Corder R, Änggård EE \& Vane JR 1993 Evidence for vesicles that transport endothelin-1 in bovine aortic endothelial cells. Fournal of Cardiovascular Pharmacology 22 S57-S60.

Harrison VJ, Barnes K, Turner AJ, Wood E, Corder R \& Vane JR 1995 Identification of endothelin 1 and big endothelin 1 in secretory vesicles isolated from bovine aortic endothelial cells. Proceedings of the National Academy of Sciences of the USA 92 6344-6348.
Heller RA \& Krönke M 1994 Tumor necrosis factor receptor-mediated signaling pathways. Fournal of Cell Biology $1265-9$.

Inoue A, Yanagisawa M, Kimura S, Kasuya Y, Miyauchi T, Goto K \& Masaki T 1989 The human endothelin family: three structurally and pharmacologically distinct isopeptides predicted by three separate genes. Proceedings of the National Academy of Sciences of the USA 86 2863-2867.

Iwamoto S, Shibuya I, Takeda K \& Takeda M 1994 Lymphotoxin lacks effects on 75-kDa receptors in cytotoxicity on U-937 cells. Biochemical and Biophysical Research Communications 199 70-77.

Loetscher H, Pan YC, Lahm HW, Gentz R, Brockhaus M, Tabuchi H \& Lesslauer W 1990 Molecular cloning and expression of the human $55 \mathrm{kd}$ tumor necrosis factor receptor. Cell 61 351-359.

Loetscher H, Stueber D, Banner D, Mackay F \& Lesslauer W 1993 Human tumor necrosis factor alpha (TNF alpha) mutants with exclusive specificity for the $55-\mathrm{kDa}$ or $75-\mathrm{kDa}$ TNF receptors. Fournal of Biological Chemistry 268 26350-26357.

Malek AM, Greene AL \& Izumo S 1993 Regulation of endothelin 1 gene by fluid shear stress is transcriptionally mediated and independent of protein kinase C and cAMP. Proceedings of the National Academy of Sciences of the USA 90 5999-6003.

Marsden PA \& Brenner BM 1992 Transcriptional regulation of the endothelin-1 gene by TNF-alpha. American Fournal of Physiology 262 C854-C861.

Ohkubo S, Ogi K, Hosoya M, Matsumoto H, Suzuki N, Kimura C, Ondo H \& Fujino M 1990 Specific expression of human endothelin-2 (ET-2) gene in a renal adenocarcinoma cell line. Molecular cloning of cDNA encoding the precursor of ET-2 and its characterization. FEBS Letters 274 136-140.

Russell FD \& Davenport AP 1999 Secretory pathways in endothelin synthesis. British Fournal of Pharmacology 126 391-398.

Russell FD, Skepper JN \& Davenport AP 1998 Human endothelial cell storage granules. A novel intracellular site for isoforms of the endothelin-converting enzyme. Circulation Research 83 314-321.

Schmidt M, Kroger B, Jacob E, Seulberger H, Subkowski T, Otter R, Meyer T, Schmalzing G \& Hillen H 1994 Molecular characterization of human and bovine endothelin converting enzyme (ECE-1). FEBS Letters $356238-243$.

Schuppin GT \& Rhodes CJ 1996 Specific co-ordinated regulation of $\mathrm{PC} 3$ and $\mathrm{PC} 2$ gene expression with that of preproinsulin in insulin-producing beta TC3 cells. Biochemical Fournal 313 259-268.

Schweizer A, Valdenaire O, Nelböck P, Deuschle U, Dumas Milne Edwards JB, Stumpf JG \& Löffler BM 1997 Human endothelin-converting enzyme (ECE-1): three isoforms with distinct subcellular localizations. Biochemical fournal 328 871-877.

Schweizer A, Löffler BM \& Rohrer J 1999 Palmitoylation of the three isoforms of human endothelin-converting enzyme-1. Biochemical fournal 340 649-656.

Shimada K, Takahashi M \& Tanzawa K 1994 Cloning and functional expression of endothelin-converting enzyme from rat endothelial cells. Fournal of Biological Chemistry 269 $18275-18278$.

Shimomoto H, Hasegawa Y, Nozaki Y, Takagi N, Shibagaki T, Nakao A \& Shimokata K 1995 Expression of tumor necrosis factor receptors in human lung cancer cells and normal lung tissues. American Fournal of Respiratory Cell and Molecular Biology 13 271-278. 
Takahashi M, Fukuda K, Shimada K, Barnes K, Turner AJ, Ikeda M, Koike H, Yamamoto Y \& Tanzawa K 1995 Localization of rat endothelin-converting enzyme to vascular endothelial cells and some secretory cells. Biochemical Fournal 311 657-665.

Turner AJ \& Tanzawa K 1997 Mammalian membrane metallopeptidases: NEP, ECE, KELL, and PEX. FASEB fournal 11 355-364.

Turner AJ, Barnes K, Schweizer A \& Valdenaire O 1998 Isoforms of endothelin-converting enzyme: why and where? Trends in Pharmacological Sciences 19 483-486.

Valdenaire O, Rohrbacher E \& Mattei MG 1995 Organization of the gene encoding the human endothelin-converting enzyme (ECE-1). Fournal of Biological Chemistry 270 29794-29798.

Valdenaire O, Lepailleur-Enouf D, Egidy G, Thouard A, Barret A, Vranckx R, Tougard C \& Michel J-P 1999 A fourth isoform of endothelin-converting enzyme (ECE-1) is generated from an additional promoter. Molecular cloning and characterization. European Fournal of Biochemistry 264 341-349.

Xu D, Emoto N, Giaid A, Slaughter C, Kaw S, deWit D \& Yanagisawa M 1994 ECE-1: a membrane-bound metalloprotease that catalyzes the proteolytic activation of big endothelin-1. Cell 78 473-485.
Yanagisawa M, Kurihara H, Kimura S, Tomobe Y, Kobayashi M, Mitsui Y, Yazaki Y, Goto K \& Masaki T 1988 A novel potent vasoconstrictor peptide produced by vascular endothelial cells. Nature 332 411-415.

Yanagisawa H, Yanagisawa M, Kapur RP, Richardson JA, Williams SC, Clouthier DE, de Wit D, Emoto N \& Hammer RE 1998 Dual genetic pathways of endothelin-mediated intercellular signaling revealed by targeted disruption of endothelin converting enzyme-1 gene. Development 125 825-836.

Yorimitsu K, Shinmi O, Nishiyama M, Moroi K, Sugita Y, Saito T, Inagaki Y, Masaki T \& Kimura S 1992 Effect of phosphoramidon on big endothelin-2 conversion into endothelin-2 in human renal adenocarcinoma (ACHN) cells. Analysis of endothelin-2 biosynthetic pathway. FEBS Letters 314 395-398.

Yorimitsu K, Moroi K, Inagaki N, Saito T, Masuda Y, Masaki T, Seino S \& Kimura S 1995 Cloning and sequencing of a human endothelin converting enzyme in renal adenocarcinoma (ACHN) cells producing endothelin-2. Biochemical and Biophysical Research Communications 208 721-727.

RECEIVED 24 August 1999 